\title{
Parallel interactions of aromatic and heteroaromatic molecules
}

\author{
Dušan P. Malenov ${ }^{1}$, Snežana D. Zarici ${ }^{1,2}$ \\ ${ }^{1}$ Faculty of Chemistry, University of Belgrade, Belgrade, Serbia \\ ${ }^{2}$ Department of Chemistry, Texas A\&M University of Qatar, Doha, Qatar
}

\begin{abstract}
Parallel interactions of aromatic and heteroaromatic molecules are very important in chemistry and biology. In this review, recent findings on preferred geometries and interaction energies of these molecules are presented. Benzene and pyridine were used as model systems for studying aromatic and heteroaromatic molecules, respectively. Searches of Cambridge Structural Database show that both aromatic and heteroaromatic molecules prefer interacting at large horizontal displacements, even though previous calculations showed that stacking interactions (with offsets of about $1.5 \AA$ ) are the strongest. Calculations of interaction energies at large horizontal displacements revealed that the large portion of interaction energy is preserved even when two molecules do not overlap. These substantial energies, as well as the possibility of forming larger supramolecular structures, make parallel interactions at large horizontal displacements more frequent in crystal structures than stacking interactions.
\end{abstract}

Keywords: benzene, pyridine, noncovalent interactions, crystal structures, quantum chemical calculations, supramolecular structures.

\section{REVIEW PAPER}

UDC 54:544.18:547.53:547.821

Hem. Ind. 70 (6) 649-659 (2016)

doi: 10.2298/HEMIND151009003M

Available online at the Journal website: http://www.ache.org.rs/HI/

Aromatic and heteroaromatic molecules are ubiquitous in nature and play important roles in processes of chemical and biological recognition. These molecules are commonly present in materials, crystals, nanosystems, and biological systems and drugs [1-8].

There are various types of noncovalent interactions that include aromatic and heteroaromatic molecules, and they are mostly formed through their $\pi$-systems [8]. The most vital interactions of these molecules are stacking interactions, which are essential for the structure of DNA [9] and for the stabilization of protein structure [10]. Other types of interactions via aromatic $\pi$-system include $\mathrm{XH} / \pi$ (where $\mathrm{X}$ can be $\mathrm{O}, \mathrm{N}, \mathrm{C}$ or $\mathrm{S}$ ), cation $/ \pi$ and anion $/ \pi$ interactions [11-39]. Additionally, aromatic molecules can form interactions through their edges, most notably classical hydrogen bonds and $\mathrm{CH}-\mathrm{O}$ interactions [40-42].

Basic model system for studying aromatic-aromatic interactions is benzene dimer. Interaction energy calculations at high theoretical levels showed that there are two nearly isoenergetic minima at potential energy surface of benzene dimer. In first of these minima, two benzenes form aromatic $\mathrm{CH} / \pi$ interactions when $\mathrm{C}-\mathrm{H}$ bonds of one benzene interact with $\pi$-system of another benzene; this minimum is global and has interaction energy of $-2.84 \mathrm{kcal} / \mathrm{mol}$, as determined by

Correspondence: S.D. Zarić, Faculty of Chemistry, University of Belgrade, Studentski trg 12-16, 11000 Belgrade, Serbia.

E-mail: szaric@chem.bg.ac.rs

Paper received: 9 October, 2015

Paper accepted: 14 January, 2016
$\operatorname{CCSD}(\mathrm{T}) / \mathrm{CBS}$ calculations [43]. Second minimum has the energy of $-2.73 \mathrm{kcal} / \mathrm{mol}$ (also at $\operatorname{CCSD}(\mathrm{T}) / \mathrm{CBS}$ level) [43], with geometry of stacking interaction, where two benzenes are mutually parallel, with horizontal displacement of approximately $1.5 \AA$ (Figure 1).

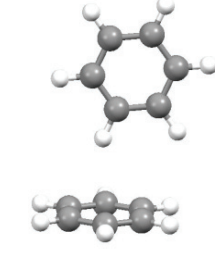

aromatic $\mathrm{CH} / \pi$

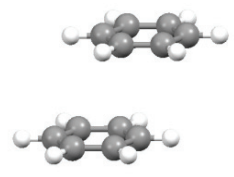

stacking
Figure 1. Benzene dimer with aromatic $\mathrm{CH} / \pi$ interaction (global minimum) and stacking interaction (local minimum).

Basic model system for studying heteroaromaticheteroaromatic interactions is pyridine dimer. Interactions between two pyridine molecules were calculated at high levels of quantum chemistry, giving two energy minima, similar to ones found for benzenebenzene dimer [43]. Stacking interactions of two pyridines are, however, somewhat stronger than $\mathrm{CH} / \pi$ interactions (interaction energies are -3.80 and -3.56 $\mathrm{kcal} / \mathrm{mol}$, respectively) [44] (Figure 2).

The importance of parallel interactions prompted new research regarding benzene dimer and pyridine dimer, as well as combined benzene-pyridine dimer. In this review, we will summarize recent findings about interactions in these systems. These results are based on analysis of crystal structures and theoretical calcul- 
ations of interaction energies. Special attention is given to interactions at large horizontal displacements, which were shown to be substantial and very important in the last few years [45-53].

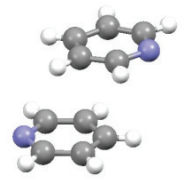

stacking

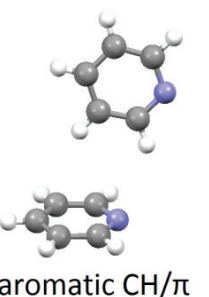

aromatic $\mathrm{CH} / \pi$
Figure 2. Pyridine dimer with stacking interaction (global minimum) and aromatic $\mathrm{CH} / \pi$ interaction (local minimum).

\section{Benzene-benzene parallel interactions}

In order to gain full knowledge on benzene-benzene parallel interactions, Cambridge Structural Database was searched for parallel benzene-benzene contacts by using less restrictive criteria than previous studies [51]. The search involved crystal structures from CSD November, 2010, release (version 5.32) that contain two benzene molecules with distance $(d)$ between their centers shorter than $6.0 \AA$, interplanar angle smaller than $10^{\circ}$ and normal distance $(R)$ between their planes shorter than $4.0 \AA$ (Figure 3).

This search yielded 1824 parallel benzene-benzene contacts. The analysis of geometrical parameters revealed that benzene molecules prefer interactions at large horizontal displacements (Figure 4a), with $64 \%$ of all contacts (1173 of 1824) at offsets values larger than $4.5 \AA$. The peak of this distribution is for offsets between 4.5 and $5.5 \AA$; since in benzene molecule hydrogen atoms are at $2.5 \AA$ of benzene center, at these offset values only hydrogen atoms of benzene molecules overlap (Figure 3 ). These results show that the most stable geometry of stacking interactions, with offsets at $1.5 \AA$, is not typical for benzene-benzene

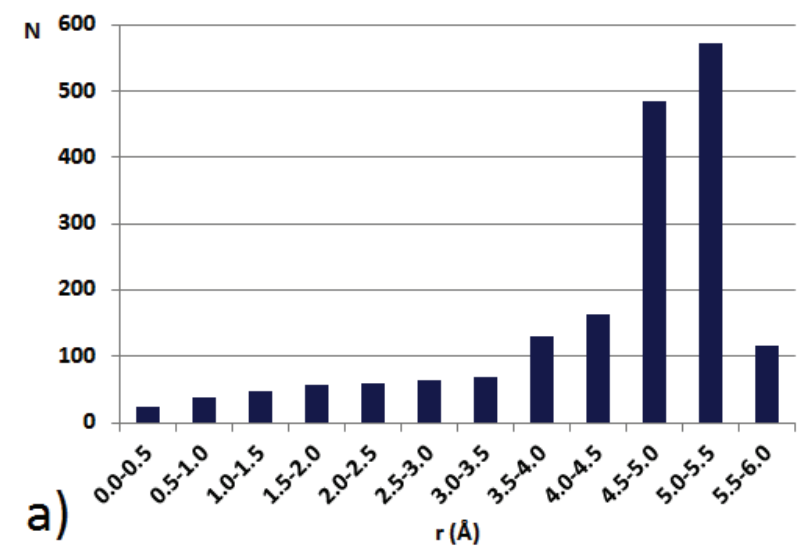

interactions. It can also be noted that for contacts with offset values below $3.5 \AA$ all normal distances are in range from 3.0 to $4.0 \AA$, with most of them being around $3.5 \AA$, which is typical for stacking interactions [54-56]. However, for horizontal displacements larger than $4.5 \AA$ normal distances are mostly lower than 3.0 $\AA$ (Figure 4b).

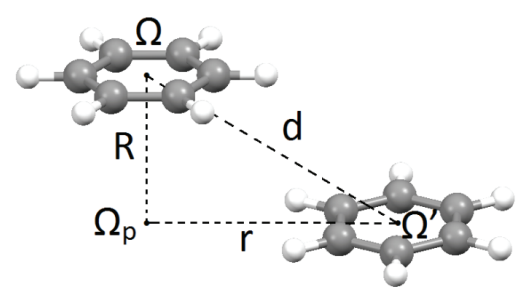

Figure 3. Geometrical parameters of parallel benzene-benzene interactions; $d$ is the distance between the centers $(\Omega$ and $\Omega^{\prime}$ ) of benzene molecules; $R$ is the normal distance between the planes of interacting rings; $\Omega_{p}$ is the projection of the center of one ring to the plane of the other ring; $r$ is horizontal displacement (offset) the distance from $\Omega^{\prime}$ to $\Omega_{p}$; the angle between benzene planes is smaller than $10^{\circ}$. In this figure, geometry with $r=5.0 \AA$ is presented.

CSD search for benzene-benzene interactions was supplemented with Protein Data Bank search for phenylalanine-phenylalanine interactions. The full protein set was reduced by using PDBSELECT list of non-redundant protein chains (November, 2012, release), the threshold being $25 \%$ and with resolution of $3.0 \AA$ or better. The search parameters were similar to those for the CSD search (Figure 3), and the contacts were included if they are within the area corresponding to the ellipsoid defined by offset $(r)$ of $7.0 \AA$ and normal distance $(R)$ of $6.0 \AA$ [53]. Search results show that in protein structures there is only slightly larger preference for offsets above $3.0 \AA$ over offsets below $3.0 \AA$ (Figure $5 \mathrm{a}$ ), hence that interactions in proteins show larger preference to geometries corresponding to the most stable stacking interaction at $1.5 \AA$, differently

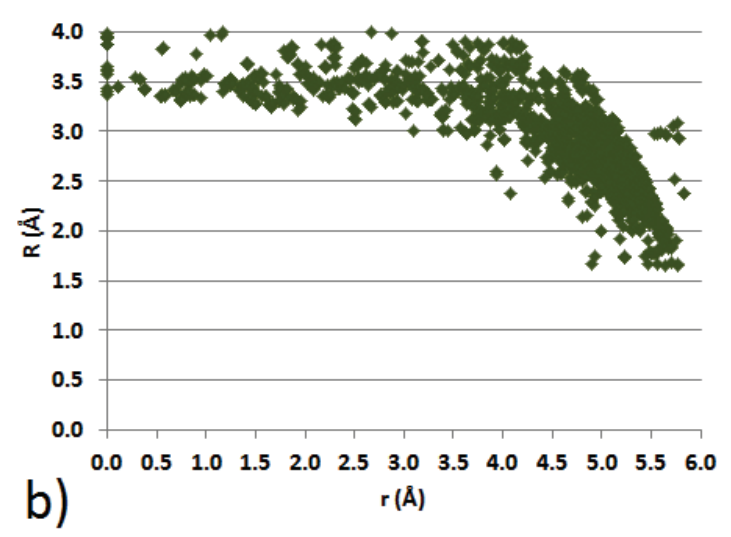

Figure 4. The distribution of offset values (a) and normal distances versus offset values plot (b) for parallel interactions between benzene molecules in CSD crystal structures. 
than in case of interactions in the CSD (Figure 4a). The shape of the plot showing normal distances versus offset values (Figure $5 b$ ) is similar to the shape of the diagram for interactions in the CSD (Figure 4b) [51].

Interaction energies between parallel benzene molecules were calculated with B2PLYP density functional [57] by using the second generation Grimme dispersion correction (D2) [58] and def2-TZVP basis set [59]. Three orientations were considered (Figure 6). Monomer geometries were kept unchanged and offset values were varied in the range $0.0-6.0 \AA$ with a $0.5 \AA$ step in order to find the optimal normal distance for each horizontal displacement [51]. Basis set superposition error (BSSE) was not corrected in these calcul- ations, since this functional is parameterized to give good results for aromatic-aromatic interactions without this correction [60].

Face-to-face or sandwich geometry, with offset of $r=0.0 \AA$, is the first stationary point and has the energy of $-1.60 \mathrm{kcal} / \mathrm{mol}$ (Figure $7 \mathrm{a}$ ), which is in good agreement with previous calculations of interaction energies [43]. The strongest interaction in all orientations is in the offset range 1.5-2.0 $\AA$, with energies of about -2.8 $\mathrm{kcal} / \mathrm{mol}$, which is also in good agreement with earlier studies [43]. Further increase of offset values leads to weaker interactions. For orientation A interaction energy change is steep. However, for orientations B and $\mathrm{C}$, interactions are surprisingly strong at large hori-
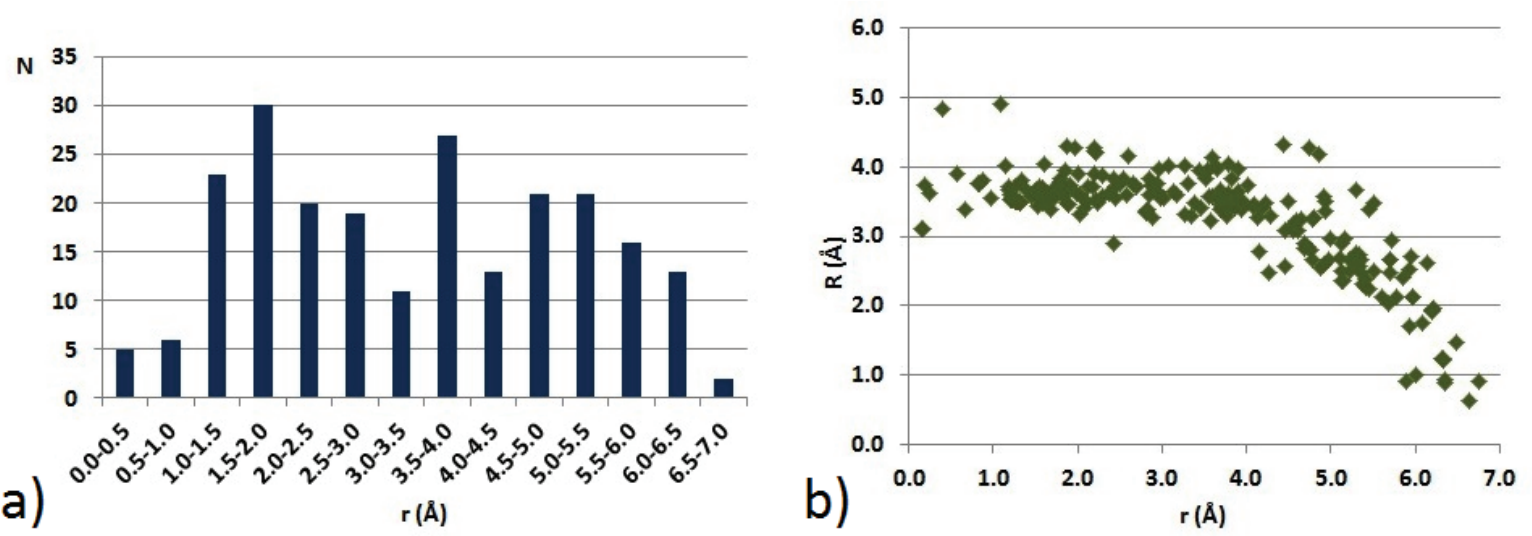

Figure 5. The distribution of offset values (a) and normal distances versus offset values plot (b) for parallel interactions between phenylalanine side chains in PDB crystal structures.
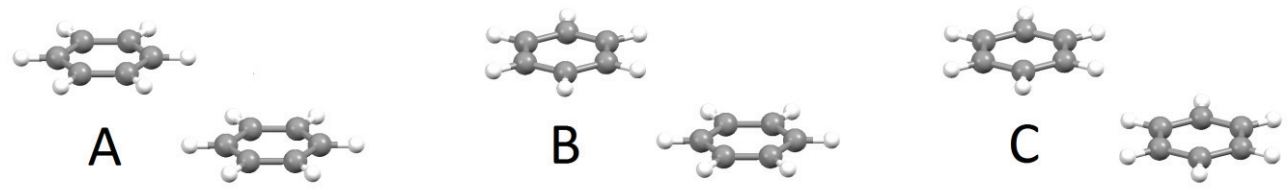

Figure 6. Three model systems with different mutual orientations of benzene molecules used for calculations of energies of parallel interactions between benzene molecules. The presented geometries are with horizontal displacements of $5.0 \AA$.
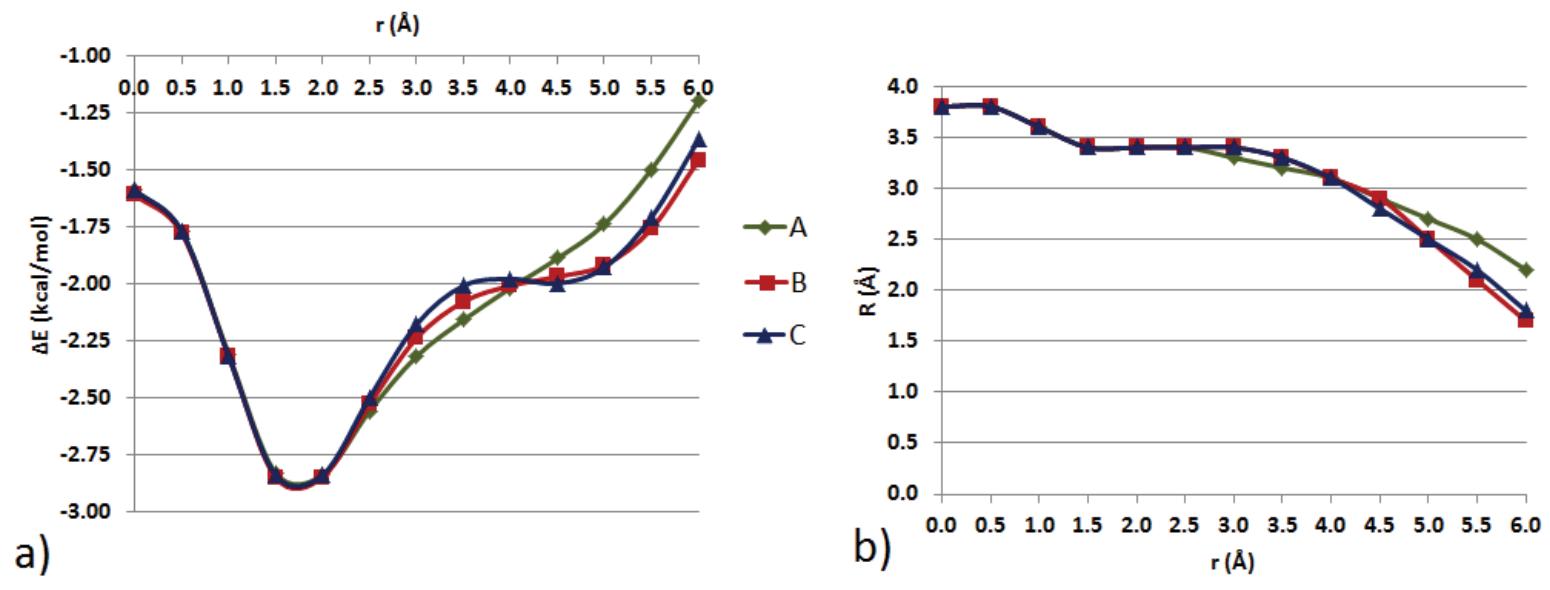

Figure 7. Interaction energies ( $\triangle E$ ) for parallel interactions of benzene molecules (model systems $A$, B and C, Figure 6) for offset values from 0.0 to $6.0 \AA$ (a) and plot of normal distances $(R)$ versus offsets ( $r$ ) for geometries with these energies $(b)$. 
zontal displacements. Interaction energy for orientation $C$ at $r=4.5 \AA$ is $-2.0 \mathrm{kcal} / \mathrm{mol}$, which is more than $70 \%$ of the strongest interaction at $r=1.5 \AA$ (Table 1). It can be considered that B2PLYP-D2 is very reliable method for these calculations, since the calculated CCSD(T)/CBS value for orientation $B$ at this offset is $-1.98 \mathrm{kcal} / \mathrm{mol}$. Substantial interaction energies at these offsets are the consequence of large reduction of repulsion and somewhat smaller reduction of dispersion, as observed by comparing B3LYP (without dispersion) and B3LYP-D2 interaction energies. The calculated normal distances are in excellent agreement with normal distances in CSD crystal structures (Figure $4 \mathrm{~b}$ ). At horizontal displacements larger than $4.0 \AA$, normal distances are lower than $3.0 \AA$, and for $r>5.0 \AA$ they are even lower than $2.0 \AA$ (Figure 7b).

Table 1. Interaction energies ( $\Delta E / \mathrm{kcalmol}^{-1}$ ) between benzene molecules with different interplanar angles at different offsets; "\%" denotes percentage of the strongest interaction energy (at $r=1.5 \AA, 100 \%)$

\begin{tabular}{|c|c|c|c|c|c|}
\hline \multirow{3}{*}{ Interplanar angle, ${ }^{\circ}$} & \multicolumn{5}{|c|}{$r / \AA$} \\
\hline & \multirow{2}{*}{$\begin{array}{l}1.5 \\
\Delta E\end{array}$} & \multicolumn{2}{|c|}{3.5} & \multicolumn{2}{|c|}{4.5} \\
\hline & & $\Delta E$ & $\%$ & $\Delta E$ & $\%$ \\
\hline 0 & -2.85 & -2.16 & 76 & -2.00 & 70 \\
\hline 20 & -2.73 & -2.06 & 75 & -2.01 & 74 \\
\hline 40 & -2.90 & -2.13 & 73 & -2.13 & 73 \\
\hline
\end{tabular}

Detailed study on benzene/benzene potential energy surface showed similarities of interactions between benzene molecules with interplanar angles from 10 to $40^{\circ}$ (Figure 8) to interactions between two parallel benzene molecules [53]. Minimum of energy for interplanar angles of 0,20 and $40^{\circ}$ was found to be at $r=1.5 \AA$ and interaction energies are very similar (Table 1). At horizontal displacements of 3.5 and $4.5 \AA$, interaction energies for interplanar angles of 20 and $40^{\circ}$ are also substantial (from -2.01 to $-2.13 \mathrm{kcal} / \mathrm{mol}$, Table 1), which is more than $70 \%$ of the strongest interaction energy, as it was previously determined for parallel benzene-benzene contacts [51]. For interplanar angles over $50^{\circ}$, potential energy curves are different, with no substantial interaction energies for offsets larger than $4.0 \AA$ indicating aromatic $\mathrm{C}-\mathrm{H} / \pi$ nature of interactions (Figure 9) [53].

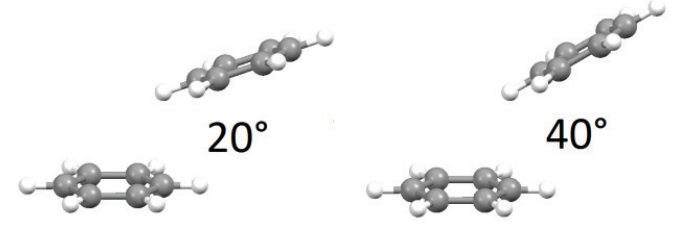

Figure 8. Model system for calculations of benzene-benzene interaction energies for interplanar angles of 20 and $40^{\circ}$; geometries with $r=3.5 \AA$ are presented.

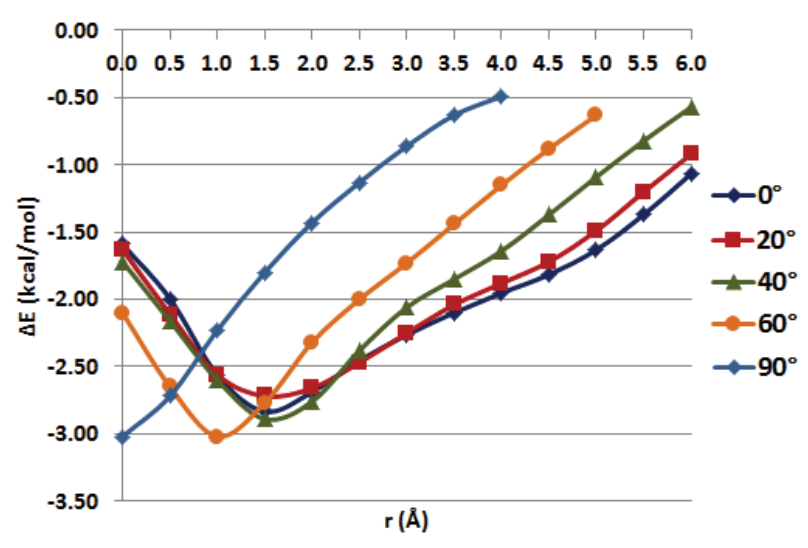

Figure 9. Curves of interaction energies between benzene molecules with interplanar angles of $0,20,40,60$, and $90^{\circ}$, calculated at B2PLYP-D2/def2-TZVP level.

There is a disagreement between results of the CSD search and interaction energy calculations for parallel benzene-benzene interactions. The CSD data show that the most frequent geometries in the CSD are with large horizontal displacements, while DFT calculations show the strongest interactions are in stacking area ( $r$ 1.5$-2.0 \AA$ A) [51]. However, mutually parallel benzene molecules have tendency to form simultaneous interactions with surrounding molecules if they are at large horizontal displacements (Figure 10). For interactions at large horizontal displacements, both faces of benzene rings can simultaneously interact with surrounding molecules. However, for interactions at smaller horizontal displacement, one face of each benzene is prevented from forming simultaneous interactions. The additional simultaneous interactions of faces, along with additional interactions of edges (e.g., $\mathrm{C}-\mathrm{H}$ can form $\mathrm{CH}-\mathrm{O}$ interactions, Figure 10), provide further stabilization of supramolecular structures, with interactions at large offsets, in crystals [51]. Together with substantial interaction energies, these simultaneous interactions are the reason for frequent appearance of parallel benzene-benzene interactions at large horizontal displacements in crystal structures.

\section{Pyridine-Pyridine Parallel Interactions}

Parallel pyridine-pyridine interactions were studied by performing the Cambridge Structural Database search on November, 2011, release (version 5.33) [52]. Similar parameters to those for benzene-benzene parallel interactions were set (Figure 11). Contacts that include hydrogen bonds between pyridine molecules and $\mathrm{X}-\mathrm{H}$ species (where $\mathrm{X}$ can be $\mathrm{O}, \mathrm{N}, \mathrm{S}, \mathrm{F}$ or $\mathrm{Cl}$ ) were excluded from this search data set, since previous investigations showed large influence of hydrogen bonding on pyridine-pyridine stacking [62].

The search derived 166 parallel pyridine-pyridine contacts. The torsion angle $T\left(N-\Omega-\Omega^{\prime}-N^{\prime}\right.$, Figure 11) showed high preference for head-to-tail orientation, 
a)

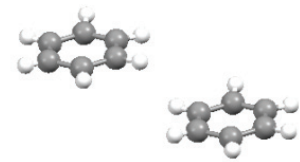

b)
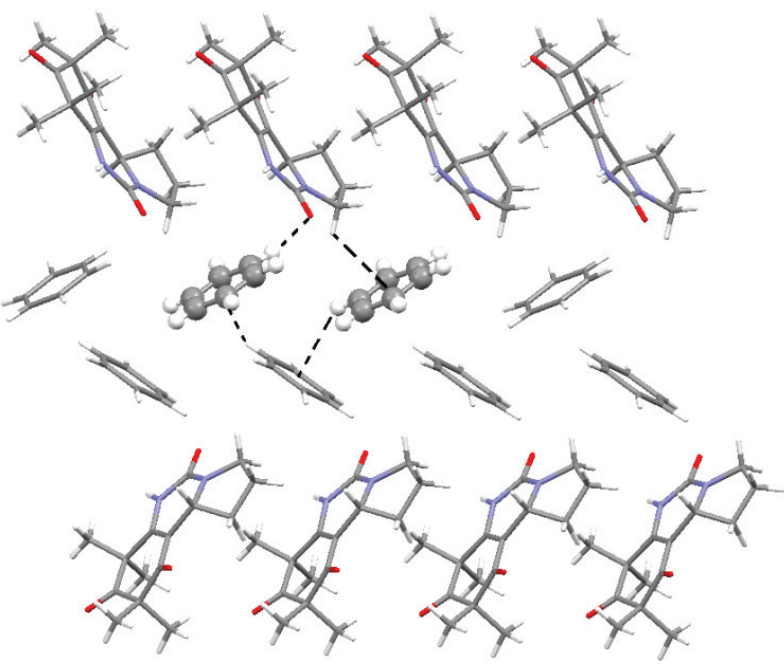

Figure 10. Parallel benzene-benzene interaction at large horizontal displacement ( $r=5.10 \AA)$ in crystal structure syncarpurea benzene solvate (CENNUE, a) [61]; both benzene molecules form additional aromatic $\mathrm{CH} / \pi$ interactions with surrounding benzene molecules, $\mathrm{CH} / \pi$ interactions with syncarpurea molecules and $\mathrm{CH} / \mathrm{O}$ interactions with $\mathrm{O}$-atoms of syncarpurea molecules (b).

which is the most stable orientation found by previous quantum chemical calculations [44].

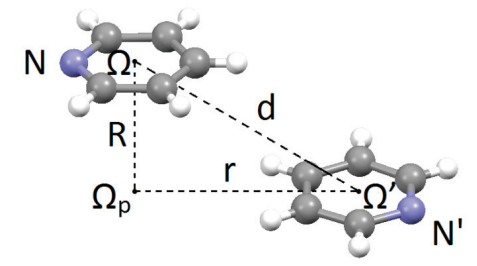

Figure 11. Geometrical parameters of parallel pyridine-pyridine interactions; $d$ is the distance between the centers $(\Omega$ and $\Omega^{\prime}$ ) of pyridine molecules; $R$ is the normal distance between the planes of interacting rings; $\Omega_{p}$ is the projection of the center of one ring to the plane of the other ring; $r$ is horizontal displacement (offset) the distance from $\Omega^{\prime}$ to $\Omega_{p}$; torsion angle $T$ is $N-\Omega-\Omega^{\prime}-N^{\prime}$ torsion angle; the angle between pyridine planes is smaller than $10^{\circ}$.

The plot of normal distances versus offset values (Figure 12a) and distribution of offset values (Figure 12b) showed high preference for horizontal displacements larger than $4.0 \AA$ ( $74 \%$ of all the contacts), similar to benzene-benzene interactions. All of the contacts at horizontal displacements lower than $4.0 \AA$ have normal distances in the range from 3.0 to $4.0 \AA$, while for larger offset values normal distances can be lower than $3.0 \AA$, and even lower than $2.0 \AA$ (Figure 12b).

Calculations of interaction energies between two parallel pyridine molecules were performed at B2PLYP-D2/def2-TZVP level of theory [57-59], without BSSE correction [60]. Only model systems with head-to-tail orientations were considered (Figure 13), due to almost unanimous preference for torsion angles $T$ close to $180^{\circ}$ in contacts found in the CSD [52]. Due to lower symmetry of pyridine in comparison to benzene, all model systems had two subsystems, labeled as $(+)$ and $(-)$, where $(+)$ denotes that rigid monomers displaced in the way nitrogen atom of one ring moves away from
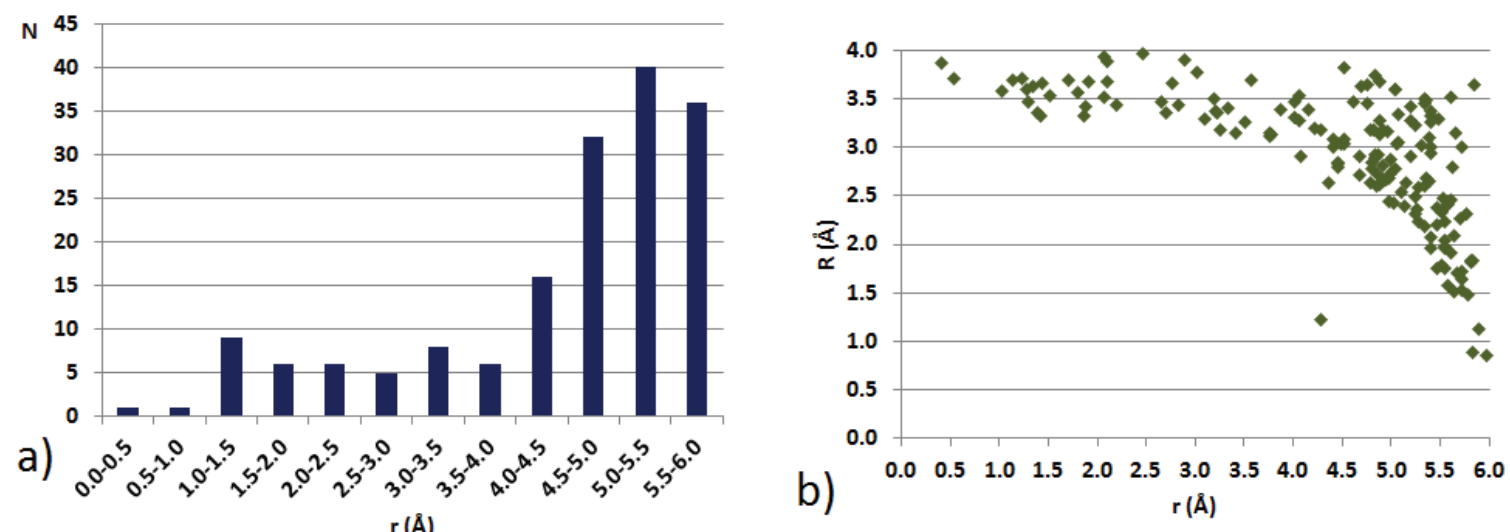

Figure 12. The distribution of offset values (a) and normal distances versus offset values plot (b) for parallel interactions of pyridine molecules in CSD crystal structures. 
the other ring, while (-) means that at small horizontal displacements nitrogen of one ring is placed above the other ring (Figure 13) [52]. The subsystems (+) and (-) are equivalent for model system $\mathrm{C}$.
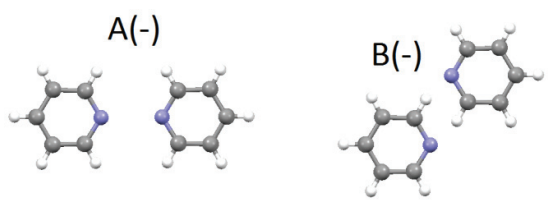

C(-)
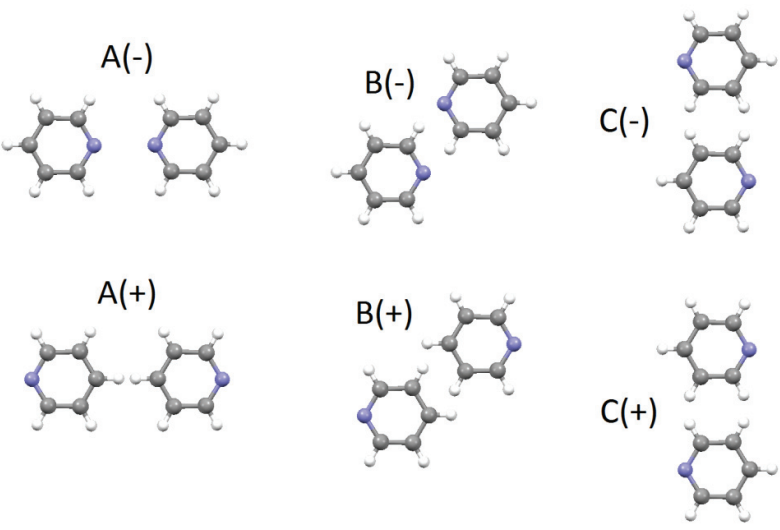

Figure 13. Top view of parallel pyridine-pyridine orientations used for calculations of interaction energies; geometries with positive (+) and negative (-) offset values of $5.0 \AA$ are presented.

Interaction energies are similar for positive offsets in all orientations (Figure 14a). The minimum of potential energy curve was found at $r=1.5 \AA$ for orientation $C$, with energy of $-4.12 \mathrm{kcal} / \mathrm{mol}$, which is stronger interaction than the ones calculated in previous studies [5]. This energy is also very accurate, being in good agreement with $\operatorname{CCSD}(\mathrm{T}) / \mathrm{CBS}$ value of $-3.99 \mathrm{kcal} / \mathrm{mol}$ [62].

For large positive offset values, interactions are also substantially strong, being the strongest also in model system $C$, with interaction energies of $-2.5 \mathrm{kcal} / \mathrm{mol}$ at $r=4.0 \AA$ and $-2.0 \mathrm{kcal} / \mathrm{mol}$ for $r=5.0 \AA$. This means that $60 \%$ of the strongest interaction energy is preserved at large offset of $r=4.0 \AA$ and $50 \%$ at $r=5.0 \AA$. These interactions are stronger than benzene-benzene interactions at large horizontal displacements, but their portions of the strongest interaction energies are not as strong (Table 2). The influence of heteroatom is huge, since face-to-face geometry $(r=0.0 \AA)$ is more stable than geometries at large offsets (-2.9 and -2.5 $\mathrm{kcal} / \mathrm{mol}$, respectively), which was not the case for benzene-benzene interactions (Table 2).

For negative offsets, interactions that involve nitrogen atoms are more pronounced (Figure 13). The strongest interaction at negative offsets is also with energy of $-4.12 \mathrm{kcal} / \mathrm{mol}$, since $\mathrm{C}(-)$ is equivalent to $\mathrm{C}(+)$. Other orientations are less stable due to involvement of nitrogen in repulsion, with minima at potential energy curves of -3.0 and $-3.4 \mathrm{kcal} / \mathrm{mol}$ for $A(-)$ and $B(-)$, respectively. In orientation $A(-)$, there are unfavorable interactions of nitrogen of one ring and nitrogen atom

a)
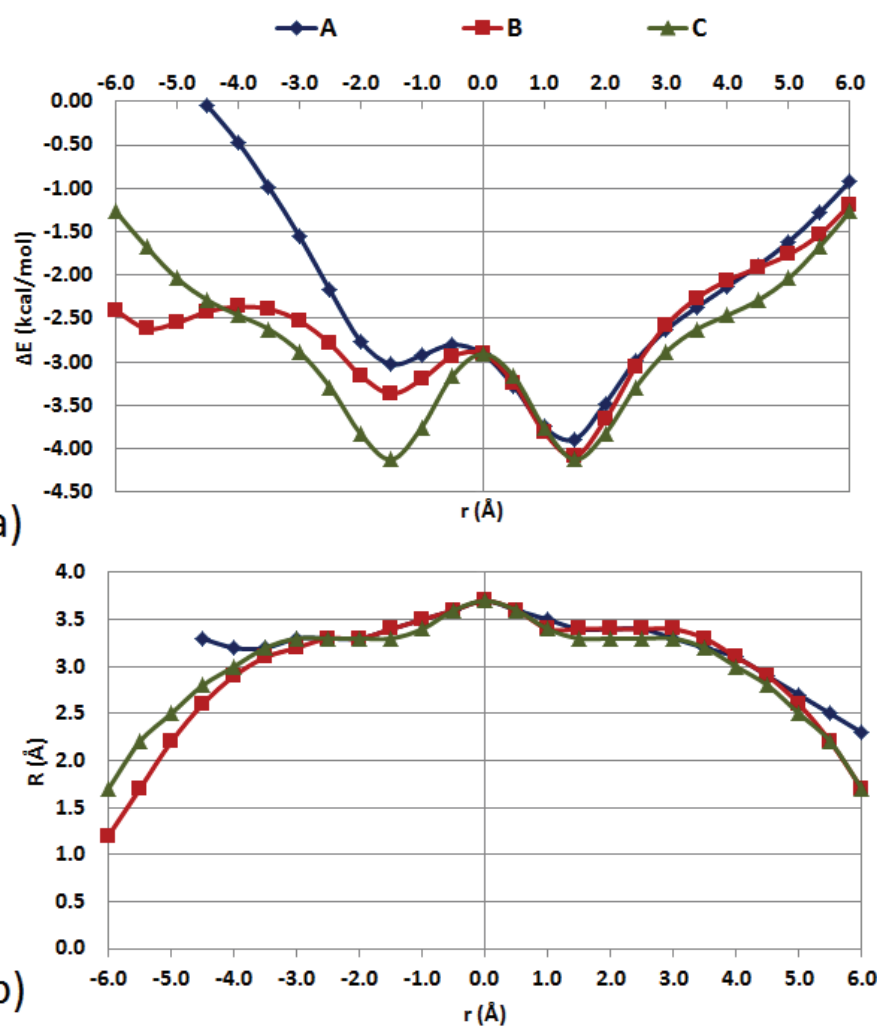

Figure 14. Interaction energies ( $\triangle E$ ) for parallel interactions of pyridine molecules (model systems $A, B$ and $C$, Figure 13 ) for offset values from -6.0 to $0.0 \AA$ and from 0.0 to $6.0 \AA$ (a) and plot of normal distances $(R)$ versus offsets $(r)$ for geometries with these energies (b). 
and center of the other ring. The interaction in this model system even becomes repulsive at $r=-4.5 \AA$, since $\mathrm{N}-\mathrm{N}$ repulsion becomes more pronounced. This is also witnessed by the fact that normal distances are never below $3.0 \AA$ (Figure 14a). For orientation $B(-)$ there is a new minimum at $r=-5.5 \AA$, with interaction energy of $-2.7 \mathrm{kcal} / \mathrm{mol}$, due to favorable $\mathrm{CH}-\mathrm{N}$ hydrogen bonds; at these offsets normal distances are even below $1.5 \AA$. Substantial interactions at large horizontal displacements are also the consequence of significant decrease in repulsion and less pronounced decrease in dispersion, similar to benzene-benzene interactions.

Table 2. Comparison of energies ( $\Delta E / \mathrm{kcal} \mathrm{mol}^{-1}$ ) of benzene-benzene, pyridine-pyridine and benzene-pyridine interactions at different horizontal displacements; "\%" denotes percentage of the strongest interaction energy, which is for $r=1.5 \AA$ in all investigated systems

\begin{tabular}{|c|c|c|c|c|c|c|c|}
\hline \multirow{3}{*}{ Interaction } & \multicolumn{7}{|c|}{$r / \AA$} \\
\hline & \multicolumn{2}{|c|}{0.0} & \multirow{2}{*}{$\frac{1.5}{\Delta E}$} & \multicolumn{2}{|c|}{4.0} & \multicolumn{2}{|c|}{5.0} \\
\hline & $\Delta E$ & $\%$ & & $\Delta E$ & $\%$ & $\Delta E$ & $\%$ \\
\hline Benzene-benzene & -1.61 & 56 & $-2.85-$ & -2.02 & 71 & -1.93 & 68 \\
\hline Pyridine-pyridine & -2.91 & 71 & $-4.12-$ & -2.46 & 60 & -2.04 & 50 \\
\hline Benzene-pyridine & -2.11 & 60 & $-3.54-$ & -2.20 & 62 & -1.95 & 55 \\
\hline
\end{tabular}

Similar to benzene-benzene interactions, supramolecular structures play crucial role in pyridine-pyridine interactions as well. The loss in energy by moving to larger offsets is easily compensated by forming additional interactions through faces of aromatic rings, which would be prevented from interacting in the structures with smaller offsets. In crystal structure KINLIC (Figure 15) both parallel pyridines at large horizontal displacements form additional aromatic and aliphatic $\mathrm{CH} / \pi$ interactions surrounding molecules [52].

\section{Benzene-pyridine parallel interactions}

Cambridge Structural Database does not contain any parallel benzene-pyridine contact that would satisfy the interaction criteria described in previous searches [52]. Therefore, only DFT study of these interactions was possible, and it was performed by using the same methodology as for pyridine-pyridine interactions [52]. Three model systems were constructed, with (+) and (-) subsystems (Figure 16), similar to pyridine-pyridine parallel interactions.
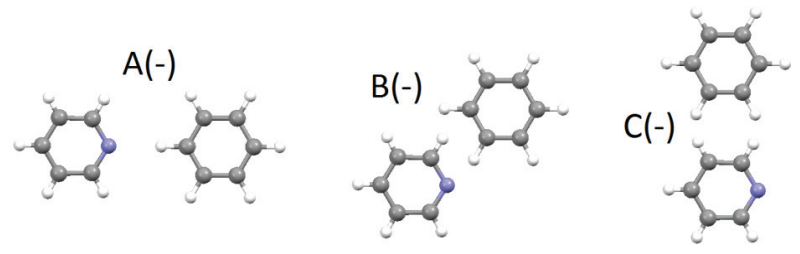

$A(+)$
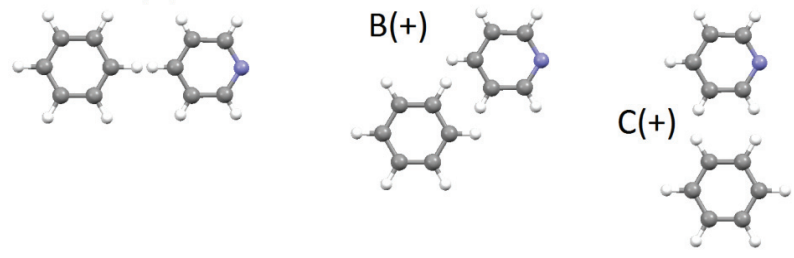

Figure 16. Top view of parallel benzene-pyridine orientations used for calculations of interaction energies; geometries with positive (+) and negative (-) offset values of $5.0 \AA$ are presented.

Minimum at potential energy curve was calculated at $r=1.5 \AA$ for orientation $\mathrm{B}(+)$, with energy of -3.54 $\mathrm{kcal} / \mathrm{mol}$, while minima for $\mathrm{A}(+)$ and $\mathrm{C}(+)$ are almost equal in energy (Figure 17a). Interactions at large horizontal displacements are also substantially strong; the strongest interaction for $r=4.0 \AA$ was in system $A(+)$, with energy of $-2.20 \mathrm{kcal} / \mathrm{mol}$, while at $r=5.0 \AA$ interaction in system $\mathrm{C}(+)$ is $-1.95 \mathrm{kcal} / \mathrm{mol}$. This means that $62 \%$ of interaction energy can be preserved at $r=4.0 \AA$, while for $r=5.0 \AA$ the percentage is only a bit lower (55\%), which is less than in benzene-benzene system, but more than in pyridine-pyridine system (Table 2 ). Benzene-pyridine interactions are similarly strong at large horizontal displacements as for face-to-face geometry (Figure 17a, Table 2).

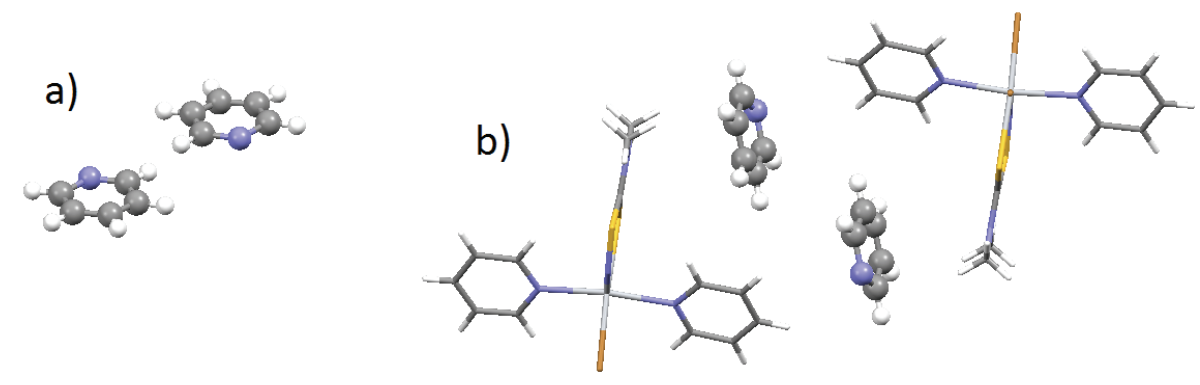

Figure 15. Parallel pyridine-pyridine interaction in crystal structure KINLIC (dibromo-(dimethylamino(thiocarbonyl)thiamin,S)-dipyridyl-titanium(IV) pyridine solvate) [63] with large horizontal displacement ( $r=4.29 \AA$, a); as a consequence of these pyridines being at large offsets, both pyridine molecules can form two additional $\mathrm{CH} / \pi$ interactions with ligands of surrounding titanium(IV) complex (b). 


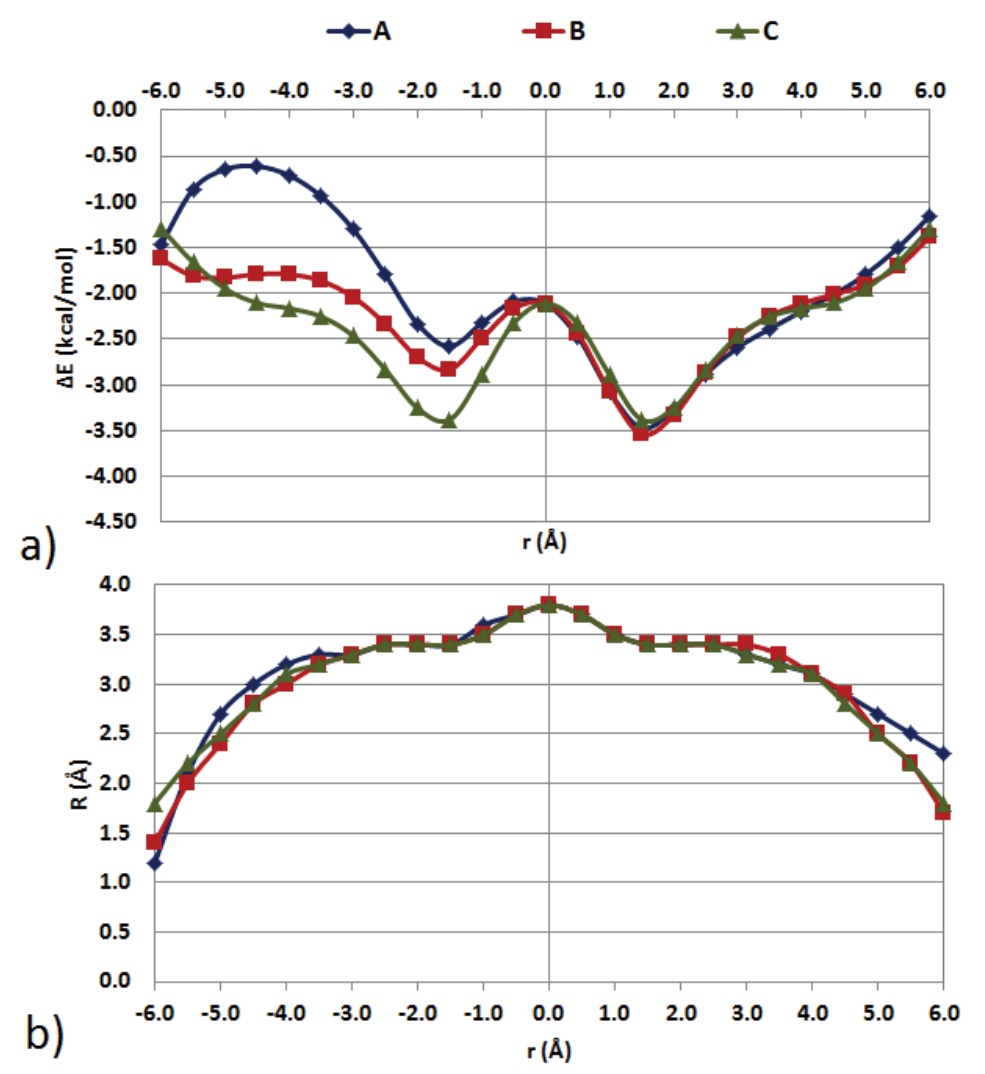

Figure 17. Interaction energies $(\Delta E)$ for parallel benzene-pyridine molecules (model systems $A$, $B$ and $C$, Figure 16) for offset values from -6.0 to $0.0 \AA$ and from 0.0 to $6.0 \AA$ (a) and plot of normal distances $(R)$ versus offsets $(r)$ for geometries with these energies $(b)$.

At negative offsets, there is a similar behavior as in pyridine-pyridine interactions, with nitrogen atom of pyridine facing some repulsion with benzene ring center. However, potential energy curve for $A(-)$ reaches maximum for $r=-4.5 \AA$ (Figure 17a), but it is never repulsive. As a consequence of only one $\mathrm{CH}-\mathrm{N}$ hydrogen bond, the minimum for benzene-pyridine $\mathrm{B}(-)$ orientation is very shallow and weaker than the same minimum for pyridine-pyridine $\mathrm{B}(-)$ orientation by 0.8 $\mathrm{kcal} / \mathrm{mol}$. Overall, at all horizontal displacements, energies of benzene-pyridine interactions are somewhere in between the energies of benzene-benzene and pyridine-pyridine interactions.

\section{CONCLUSIONS}

This review presented recent findings about parallel interactions between two aromatic molecules and between two heteroaromatic molecules, as well as between one aromatic and one heteroaromatic molecule. These studies particularly showed the importance of interactions at large horizontal displacements, i.e., out of aromatic ring and beyond the $\mathrm{C}-\mathrm{H}$ bond region.

The preference for large horizontal displacements, over $4.5 \AA$, was observed for benzene-benzene contacts in crystal structures from CSD and phenyl-phenyl contacts of phenylalanines in PDB crystal structures.
There is also a large preference for horizontal displacements over $4.5 \AA$ for pyridine-pyridine contacts in CSD crystal structures. Even though these interactions are weaker than classical stacking interactions, their interaction energies are surprisingly strong, with values of $-2.0 \mathrm{kcal} / \mathrm{mol}$ for benzene-benzene and $-2.5 \mathrm{kcal} / \mathrm{mol}$ for pyridine-pyridine system, which is substantial portion of the strongest stacking interaction energies (71\% for benzene-benzene and $60 \%$ for pyridine-pyridine). Also, combined benzene-pyridine system shows similar properties. These interactions are the result of significant reduction of repulsion at large horizontal displacements, followed by smaller reduction of dispersion.

Parallel interactions of aromatic and heteroaromatic molecules at large horizontal displacements are of significant importance, since they are substantially strong, and at the same time, enable aromatic rings to form additional interactions through both of their faces, therefore forming more stable supramolecular structures. They are essential for all molecular systems that contain aromatic rings, which include materials, crystals, nanosystems, drugs, and biological systems, in particular proteins and nucleic acids.

\section{Acknowledgements}

This work was supported by Ministry of Education, Science and Technological Development of the Rep- 
ublic of Serbia (grant No. 172065). The authors are grateful to Dr Horst Borrman of the Max Planck Institute for Chemical Physics of Solids in Dresden, Germany, for his support.

\section{REFERENCES}

[1] C. Bissantz, B. Kuhn, M. Stahl, A Medicinal Chemist's Guide to Molecular Interactions, J. Med. Chem. 53 (2010) 5061-5084.

[2] M.L. Ma, Y. Kuang, Y. Gao, Y. Zhang, P. Gao, B. Xu, Aromatic-Aromatic Interactions Induce the SelfAssembly of Pentapeptidic Derivatives in Water To Form Nanofibers and Supramolecular Hydrogels, J. Am. Chem. Soc. 132 (2010) 2719-2728.

[3] H. Robson Marsden, J.G.E.M. Fraaije, A. Kros, Introducing Quadrupole Interactions into the Peptide Design Toolkit, Angew. Chem. Int. Ed. 49 (2010) 8570-8572.

[4] H.J. Schneider, Binding mechanisms in supramolecular complexes, Angew. Chem. Int. Ed. 48 (2009) 3924-3977.

[5] B. Meszaros, P. Tompa, I. Simon, Z. Dosztanyi, Molecular principles of the interactions of disordered proteins, J. Mol. Biol. 372 (2007) 549-561.

[6] A. Lattanzi, C. De Fusco, A. Russo, A. Poater, L. Cavallo, Hexafluorobenzene: a powerful solvent for a noncovalent stereoselective organocatalytic Michael addition reaction, Chem. Commun. 48 (2012) 1650-1652.

[7] M.J.M. Munoz, G. Fernandez, Metallosupramolecular amphiphilic $\pi$-systems, Chem. Sci. 3 (2012) 1395-1398.

[8] L.M. Salonen, M. Ellermann, F. Diederich, Aromatic rings in chemical and biological recognition: energetics and structures, Angew. Chem. Int. Ed. 50 (2011) 4808-4842.

[9] V.L. Malinovskii, F. Samain, R. Haener, Helical arrangement of interstrand stacked pyrenes in a DNA framework, Angew. Chem. Int. Ed. 46 (2007) 4464-4467.

[10] R. Fasan, R. L.A. Dias, K. Moehle, O. Zerbe, D. Obrecht, P.R.E. Mittl, M.G. Gruetter, J.A. Robinson, Structure-activity studies in a family of beta-hairpin protein epitope mimetic inhibitors of the $\mathrm{p} 53-\mathrm{HDM} 2$ protein-protein interaction, ChemBioChem 7 (2006) 515-526.

[11] M.C. O'Sullivan, T.B. Durham, H.E. Valdes, K.L. Dauer, N.J. Karney, A.C. Forrestel, C.J. Bacchi, J.F. Baker, Dibenzosuberyl substituted polyamines and analogs of clomipramine as effective inhibitors of trypanothione reductase; molecular docking, and assessment of trypanocidal activities, Bioorg. Med. Chem. 23 (2015) 996-1010.

[12] A. Woziwodzka, G. Gołuński, D. Wyrzykowski, R. Kaźmierkiewicz, J. Piosik, Caffeine and Other Methylxanthines as Interceptors of Food-Borne Aromatic Mutagens: Inhibition of Trp-P-1 and Trp-P-2 Mutagenic Activity, Chem. Res. Toxicol. 26 (2013) 1660-1673.

[13] Y. Thio, S.W. Toh, F. Xue, J.J. Vittal, Self-assembly of a 15-nickel metallamacrocyclic complex derived from the L-glutamic acid Schiff base ligand, Dalton Trans. 43 (2014) 5998-6001.

[14] Z.D. Tomić, V.M. Leovac, S.V. Pokorni, D. Zobel, S.D. Zarić, Crystal Structure of Bis[acetone-1-naphthoylhydrazinato(-1)]copper(II) and Investigations of Intermole- cular Interactions, Eur. J. Inorg. Chem. 2003 (2003) $1222-1226$.

[15] D.N. Sredojević, Z.D. Tomić, S.D. Zarić, Evidence of Chelate-Chelate Stacking Interactions in Crystal Structures of Transition-Metal Complexes, Cryst. Growth Des. 10 (2010) 3901-3908.

[16] D.P. Malenov, D.B. Ninković, D.N. Sredojević, S.D. Zarić, Stacking of Benzene with Metal Chelates: Calculated CCSD(T)/CBS Interaction Energies and Potential-Energy Curves, ChemPhysChem 15 (2014) 2458-2461.

[17] H. Hosseini-Monfared, E. Pousaneh, S. Sadighian, S.W. Ng, E.R.T. Tiekink, Syntheses, Structures, and Catalytic Activity of Copper(II)-Aroylhydrazone Complexes, Z. Anorg. Allg. Chem. 639 (2013) 435-442.

[18] E.R.T. Tiekink, Molecular crystals by design?, Chem. Commun. 50 (2014) 11079-11082.

[19] L. Moreira da Costa, S.R. Stoyanov, S. Gusarov, P.R. Seidl, J. Walkimar de M. Carneiro, A. Kovalenko, Computational Study of the Effect of Dispersion Interactions on the Thermochemistry of Aggregation of Fused Polycyclic Aromatic Hydrocarbons as Model Asphaltene Compounds in Solution, J. Phys. Chem., A 118 (2014) 896-908.

[20] O. Takahashi, Y. Kohno, M. Nishio, Relevance of Weak Hydrogen Bonds in the Conformation of Organic Compounds and Bioconjugates: Evidence from Recent Experimental Data and High-Level ab Initio MO Calculations, Chem. Rev. 110 (2010) 6049-6076.

[21] M. Nishio, Y. Umezawa, J. Fantini, M.S. Weiss, P. Chakrabarti, $\mathrm{CH}-\pi$ hydrogen bonds in biological macromolecules, Phys. Chem. Chem. Phys. 16 (2014) 12648-12683 .

[22] A. Robertazzi, F. Krull, E.-W. Knapp, P. Gamez, Recent advances in anion- $\pi$ interactions, CrystEngComm 13 (2011) 3293-3300.

[23] V.B. Medaković, G.A. Bogdanović, M.K. Milčić, G.V. Janjić, S.D. Zarić, $\mathrm{CH} / \mathrm{pi}$ interactions in metal-porphyrin complexes with pyrrole and chelate rings as hydrogen acceptors, J. Inorg. Biochem 117 (2012) 157-163.

[24] G.V. Janjić, M.K. Milčić, S.D. Zarić, Intramolecular $\mathrm{MLOH} / \mathrm{pi}$ and $\mathrm{MLNH} / \mathrm{pi}$ interactions in crystal structures of metal complexes, Chem. Pap. 63 (2009) 298-305.

[25] D.N. Sredojević, G.A. Bogdanović, Z.D. Tomić, S.D. Zarić, Stacking vs. $\mathrm{CH}-$ pi interactions between chelate and aryl rings in crystal structures of square-planar transition metal complexes, CrystEngComm 9 (2007) 793-798.

[26] S.D. Stojanović, V.B. Medaković, G. Predović, M.V. Baljanski, S.D. Zarić, $\mathrm{XH} / \mathrm{pi}$ interactions with the pi system of porphyrin ring in porphyrin-containing proteins, J. Biol. Inorg. Chem. 12 (2007) 1063-1071.

[27] M.K. Milčić, V.B. Medaković, D.N. Sredojević, N.O. Juranić, S.D. Zarić, Electron delocalization mediates the metal-dependent capacity for $\mathrm{CH} / \mathrm{pi}$ interactions of acetylacetonato chelates, Inorg. Chem. 45 (2006) 4755$-4763$

[28] M.K. Milčić, V.B. Medaković, S.D. Zarić, CH/pi interactions of pi-system of acetylacetonato chelate ring: Comparison of $\mathrm{CH} / \mathrm{pi}$ interactions of $\mathrm{Ni}(\mathrm{II})$-acetylaceto- 
nato chelate and benzene rings, Inorg. Chim. Acta 359 (2006) 4427-4430.

[29] V.B. Medaković, M.K. Milčić, G.A. Bogdanović, S.D. Zarić, $\mathrm{C}-\mathrm{H}$ center dot center dot center dot pi interactions in the metal-porphyrin complexes with chelate ring as the H acceptor, J. Inorg. Biochem. 98 (2004) 1867-1873.

[30] G.A. Bogdanović, V.B. Medaković, M.K. Milčić, S.D. Zarić, Intramolecular $\mathrm{C}-\mathrm{H}$ center dot center dot center dot pi interactions in metal-porphyrin complexes, Int. J. Mol. Sci. 5 (2004) 174-185.

[31] M. K. Milčić, Z.D. Tomić, S.D. Zarić, Very strong metal ligand aromatic cation-pi interactions in transition metal complexes: intermolecular interaction in tetraphenylborate salts, Inorg. Chim. Acta 357 (2004) 4327$-4329$.

[32] S.D. Zarić, Metal ligand aromatic cation-pi interactions, Eur. J. Inorg. Chem. 12 (2003) 2197-2209.

[33] A. Žmirić, M.K. Milčić, S.D. Zarić, Theoretical study of metal ligand aromatic cation-pi interactions of $\left[\mathrm{Co}\left(\mathrm{NH}_{3}\right)_{(6)]}^{\left({ }^{(3+)}\right.}\right.$ with benzene, Int. J. Quant. Chem. 87 (2002) 354-359.

[34] G.A. Bogdanović, A. Spasojević-de Bire, S.D. Zarić, Evidence based on crystal structures and calculations of a $\mathrm{C}-\mathrm{H}-\ldots$ pi interaction between an organic moiety and a chelate ring in transition metal complexes, Eur. J. Inorg. Chem. 9 (2002) 1599-1602.

[35] M.K. Milčić, S.D. Zarić, Intramolecular metal ligand aromatic cation-pi interactions in crystal structures of transition metal complexes, Eur. J. Inorg. Chem. 8 (2001) 2143-2150.

[36] S.D. Zarić, D.M. Popović, E.-W. Knapp, Metal ligand aromatic cation-pi interactions in metalloproteins: Ligands coordinated to metal interact with aromatic residues, Chem. Eur. J. 6 (2000) 3935-3942.

[37] S.D. Zarić, Theoretical study of cation-pi interactions of the metal complex cation, [Co( $\left.\left.\mathrm{NH}_{3}\right)(6)\right](3+)$, with ethylene and acetylene, Chem. Phys. 256 (2000) 213-223.

[38] D.A. Dougherty, The Cation- $\pi$ Interaction, Acc. Chem. Res. 46 (2013) 885-893.

[39] P. Gamez, T.J. Mooibroek, S.J. Teat, J. Reedijk, Anion Binding Involving $\pi$-Acidic Heteroaromatic Rings, Acc. Chem. Res. 40 (2007) 435-444.

[40] D.Ž. Veljković, V.B. Medaković, J.M. Andrić, S.D. Zarić, $\mathrm{C}-\mathrm{H} / \mathrm{O}$ interactions of nucleic bases with a water molecule: a crystallographic and quantum chemical study, CrystEngComm 16 (2014) 10089-10096.

[41] D.Ž. Veljković, G.V. Janjić, S.D. Zarić, Are C-H center dot center dot center dot $O$ interactions linear? The case of aromatic CH donors, CrystEngComm 13 (2011) 5005-5010 .

[42] J.Lj. Dragelj, G.V. Janjić, D.Ž. Veljković, Crystallographic and ab initio study of pyridine $\mathrm{CH}-\mathrm{O}$ interactions: linearity of the interactions and influence of pyridine classical hydrogen bonds, CrystEngComm 15 (2013) 10481-10489 .

[43] E.C. Lee, D. Kim, P. Jurecka, P. Tarakeshwar, P. Hobza, K. S. Kim, Understanding of Assembly Phenomena by Aromatic-Aromatic Interactions: Benzene Dimer and the
Substituted Systems, J. Phys. Chem., A 111 (2007) 3446$-3457$.

[44] I. Geronimo, E.C. Lee, N.J. Singh, K.S. Kim, How Different are Electron-Rich and Electron-Deficient $\pi$ Interactions? J. Chem. Theory Comput. 6 (2010) 1931-1934.

[45] G.V. Janjić, D.ž. Veljković, S.D. Zarić, Water/Aromatic Parallel Alignment Interactions. Significant Interactions at Large Horizontal Displacements, Cryst. Growth Des. 11 (2011) 2680-2683.

[46] B.D. Ostojić, G.V. Janjić, S.D. Zarić, Parallel alignment of water and aryl rings-crystallographic and theoretical evidence for the interaction, Chem. Commun. 48 (2008) 6546-6548.

[47] D.P. Malenov, G.V. Janjić, D.Ž. Veljković, S.D. Zarić, Mutual influence of parallel, $\mathrm{CH} / \mathrm{O}, \mathrm{OH} / \mathrm{pi}$ and lone pair/pi interactions in water/benzene/water system, Comput. Theor. Chem. 1018 (2013) 59-65.

[48] D.Z. Vojislavljević-Vasilev, G.V. Janjić, V.B. Medaković, J.P. Blagojević, S.D. Zarić, Parallel Water/Aromatic Interactions of Non-Coordinated and Coordinated Water, ChemPhysChem 15 (2014) 2386-2396.

[49] G.V. Janjić, S.N. Malkov, M.V. Živkovic, S.D. Zarić, What are preferred water-aromatic interactions in proteins and crystal structures of small molecules?, Phys. Chem. Chem. Phys. 16 (2014) 23549-23553.

[50] M.P. Mitoraj, G.V. Janjić, V.B. Medaković, D.Ž. Veljković, A. Michalak, S.D. Zarić, M.K. Milčić, Nature of the Water/Aromatic Parallel Alignment Interactions, J. Comput. Chem. 36 (2015) 171-180.

[51] D.B. Ninković, G.V. Janjić, D.Ž. Veljković, D.N. Sredojević, S.D. Zarić, What Are the Preferred Horizontal Displacements in Parallel Aromatic-Aromatic Interactions? Significant Interactions at Large Displacements, ChemPhysChem 12 (2011) 3511-3514.

[52] D.B. Ninković, J.M. Andrić, S.D. Zarić, Parallel Interactions at Large Horizontal Displacement in Pyridine-Pyridine and Benzene-Pyridine Dimers, ChemPhysChem 14 (2013) 237-243.

[53] D.B. Ninković, J.M. Andrić, S.N. Malkov, S.D. Zarić, What are the preferred horizontal displacements of aromatic-aromatic interactions in proteins? Comparison with the calculated benzene-benzene potential energy surface, Phys.Chem. Chem. Phys. 16 (2014) 11173-11177.

[54] C. Janiak, A critical account on $\pi-\pi$ stacking in metal complexes with aromatic nitrogen-containing ligands, J. Chem. Soc., Dalton Trans. 2000 (2000) 3885-3896.

[55] T. Steiner, Hydrogen bonds from water molecules to aromatic acceptors in very high-resolution protein crystal structures, Biophys. Chem. 95 (2002) 195-201.

[56] T. Janowski, P. Pulay, High accuracy benchmark calculations on the benzene dimer potential energy surface, Chem. Phys. Lett. 447 (2007) 27-32.

[57] S. Grimme, Semiempirical hybrid density functional with perturbative second-order correlation, J. Chem. Phys. 124 (2006) 034108.

[58] S. Grimme, Semiempirical GGA-type density functional constructed with a long-range dispersion correction, J. Comput. Chem. 27 (2006) 1787-1799. 
[59] F. Weigend, R. Ahlrichs, Balanced basis sets of split valence, triple zeta valence and quadruple zeta valence quality for $\mathrm{H}$ to Rn: Design and assessment of accuracy, Phys. Chem. Chem. Phys. 7 (2005) 3297-3305.

[60] J.C. Sancho-Garcia, A.J. Perez-Jimenez, Assessment of double-hybrid energy functionals for pi-conjugated systems, J. Chem. Phys. 131 (2009) 084108.

[61] C.D. Hufford, B. Oguntimein, M. Martin, J. Clardy, Syncarpurea, a novel metabolite from Uvaria afzelii, Tetrahedron Lett. 25 (1984) 371-374.
[62] D.B. Ninković, G.V. Janjić, S.D. Zarić, Crystallographic and $a b$ Initio Study of Pyridine Stacking Interactions. Local Nature of Hydrogen Bond Effect in Stacking Interactions, Cryst. Growth Des. 12 (2012) 1060-1063.

[63] B. Meller-Rehbein, H.W. Roesky, M. Noltemeyer, Dibromo-(dimethylamino(thiocarbonyl)thioamido-N,S)-dipyridyl-titanium(IV) pyridine solvate, Chem. Ber. 124 (1991) 523-526.

\section{IZVOD}

\section{PARALELNE INTERAKCIJE AROMATIČNIH I HETEROAROMATIČNIH MOLEKULA}

Dušan P. Malenov ${ }^{1}$, Snežana D. Zarić ${ }^{1,2}$

${ }^{1}$ Hemijski fakultet, Univerzitet u Beogradu, Studentski trg 12-16, 11000 Beograd, Srbija
${ }^{2}$ Department of Chemistry, Texas A\&M University of Qatar, Doha, Qatar

(Pregledni rad)

Paralelne interakcije aromatičnih i heteroaromatičnih molekula su veoma važne u hemiji i biologiji. Ove interakcije igraju važne uloge u procesima hemijskog i biološkog prepoznavanja, a prisutne su i značajne u mnogim nanosistemima, lekovima, materijalima i kristalima. U ovom preglednom radu predstavljena su skorija otkrića u vezi sa preferentnim geometrijama i energijama interakcija između aromatičnih, odnosno heteroaromatičnih molekula. Ranije studije su pokazale da i aromatični i heteroaromatični molekuli grade najstabilnije paralelne interakcije kada su međusobno paralelno pomereni, tj. kada su im horizontalna pomeranja bliska vrednosti od 1,5 Å, pri čemu grade tzv. steking interakcije. Benzen i piridin su najčešće korišćeni model sistemi za proučavanje aromatičnih, odnosno heteroaromatičnih interakcija, a najstabilnije steking interakcije u dimeru benzena i dimeru piridina imaju energije od oko $-2,7 \mathrm{kcal} / \mathrm{mol}$, odnosno $-4,0 \mathrm{kcal} / \mathrm{mol}$. Pretrage Kembričke baze strukturnih podataka pokazuju da i aromatični i heteroaromatični molekuli preferiraju interakcije na velikim horizontalnim pomeranjima, iako su steking interakcije jače. Proračuni energija interakcija na velikim horizontalnim pomeranjima pokazali su da se veliki deo energije interakcije očuva čak i kada se dva molekula ne preklapaju; na horizontalnom pomeranju od 5,0 Å energije interakcije i u dimeru benzena i u dimeru piridina iznose oko $-2,0 \mathrm{kcal} / \mathrm{mol}$, što je skoro $70 \%$ energije steking interakcije dva benzena, odnosno $50 \%$ energije steking interakcije dva piridina. Vizuelna analiza kristalnih struktura pokazala je da međusobno pomeranje ovih molekula ka velikim ofsetima omogućava da $\pi$-sistem prstena (koji je inače blokiran kada se gradi steking interakcija) nagradi dodatne interakcije sa molekulima iz okruženja. Interakcije na velikim horizontalnim pomeranjima stoga omogućavaju građenje većih supramolekulskih struktura, te doprinose dodatnoj stabilizaciji čitavog sistema, pri čemu se značajan deo energije njihove međusobne interakcije očuva. Svi ovi faktori utiču na to da paralelne interakcije aromatičnih, odnosno heteroaromatičnih molekula budu frekventnije u kristalnim strukturama od steking interakcija.
Ključne reči: Benzen • Piridin • Nekovalentne interakcije • Kristalne strukture • Kvantnohemijski proračuni • Supramolekulske strukture 